\title{
DYNAMICS OF BAD DEBTS: HAS PEAK BEEN REACHED?'
}

\author{
A.Vedev, M.Khromov
}

The growth of bad assets in the banking sector slowed down significantly in 2016. This has resulted in a decrease of reserves increment against potential losses on loans and other assets and was the principal factor for restoring banking profit in 2016.

By the end of summer 2016, the volume of bad assets in the banking system had continued to be on the rise both in nominal and in percentage ratio to the overall volume, albeit at a much slower pace. If we take the overall assessment of bad assets across all types of assets as a total volume of generated reserves against potential losses then its ratio to the total volume of assets for 1 January through 1 September 2016 went up by 0.8 p.p. from $6.5 \%$ to $7.3 \%$. For the same period 2015 , the increment constituted 1.2 p.p. from $5.2 \%$ to $6.4 \%$. To be noted, the maximum of this ratio which was observed in 2010 (7.5\%) has not been reached yet, however the proper volume of reserves has already grown 2.5-fold against 2010 ( $R b 5.8$ trillion against $\mathrm{Rb} 2.3$ trillion).

Increment of the nominal volume of generated reserves against potential losses in 2016 has turned out to be nearly 2.5 times less than during the corresponding period of 2015 ( $\mathrm{Rb} 397 \mathrm{bn}$ against $\mathrm{Rb}$ 939bn). Close dynamics of the share of reserves in bank assets is explained by the fact that the nominal amount of assets for the first eight months of 2016 moved down by $4.0 \%$, meanwhile a year earlier bank assets went up by $1.0 \%$.

In certain segments of the credit market, the situation with bad debts is like this.

\section{Retail segment}

The retail segment of the credit market faced specific indicators, which characterize the quality of loans exceeded maximums of 2009-2010 already last year. The share of outstanding consumer debt by 2015 -end hit $8.4 \%$ and by 1 September 2016 went up by another 0.6 p.p. to $9.0 \%$. In 2010 maximum totaled to $7.7 \%$.

The volume of the outstanding consumer debt increased in JanuaryAugust 2016 by $\mathrm{Rb} 66 \mathrm{bn}$, while its growth over the same period of last year was $\mathrm{Rb} 208 \mathrm{bn}$. Additional factor for the past due debt growth is the ongoing reduction of the nominal volume of consumer debt on bank credits. As of 1 September 2016, consumer debt before banks fell by $0.4 \%$ against 1 January 2016.

The volume of generated reserves against potential losses on consumer credits has gone up over 8 months of 2016 by Rb $26 \mathrm{bn}$ (2.1\%), which is significantly slower than a year earlier ( $\mathrm{Rb} 162 \mathrm{bn}$ and $15.3 \%$ over the corresponding period of 2015). The ratio of generated reserves against potential losses on consumer loans and the volume of consumer debt on bank loans hit $11.5 \%$,

1 This paper was originally published in Online Monitoring of Russia's Economic Outlook No.15(33). 
having grown by 0.3 p.p. compared to the turn of the year. In 2010, this indicator's maximum reached $10.9 \%$ (Fig. 1)

\section{Corporate sector}

From the point of view of bad debt, corporate loans do not exceed previous maximum. During eight months of 2016, the volume of past due corporate debt has moved up by $\mathrm{Rb} 141 \mathrm{bn}$ (7.9\%), which is 3.6-fold less than a year earlier ( $\mathrm{Rb} 514 \mathrm{bn}$ or $48 \%$ ). Its share in overall volume of corporate loans has gone up by 0.6 p.p. from the turn of 2016 and hit $6.6 \%$ as of 1 September 2016, which corre-

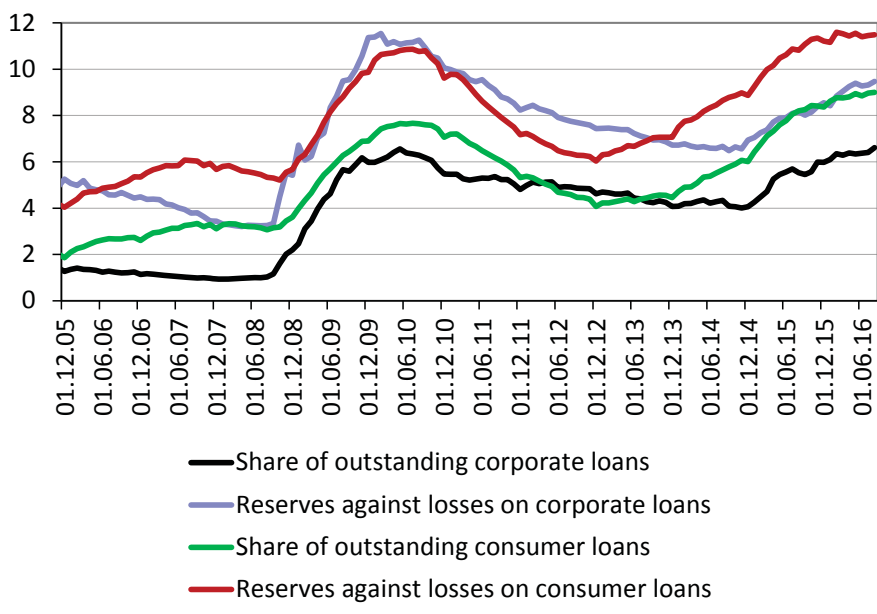

Fig. 1. Indicators of bank loans quality, $\%$ sponds its maximum posted in 2010.

The increment of the reserve volume against potential losses on corporate loans fell by 2.5-fold in comparison with the same period of 2015 ( $R b 201 \mathrm{bn}$ against $\mathrm{Rb} 507 \mathrm{bn}$ ). The ratio of reserves to the amount of the corporate credit portfolio has gone up to $9.5 \%$, which is noticeably below the level posted in 2010 (11.5\%).

\section{Quality of assets}

Thus, during 8 months of 2016, the trend to deterioration of bank asset quality remains. However, unmasking of bad assets has been going much slower this year compared to 2015. Relative level of bad assets has exceeded the maximum of 2009--2010 solely in the retail segment of the credit market. On the whole, the share of bad assets is still lower.

Regarding certain groups of banks, the best asset quality remains in Sberbank and banks owned by non-residents. As of 1 September 2016, the share of reserves against potential losses across all types of assets to total assets constituted $5.3 \%$ in Sberbank, and $5.5 \%$ in foreign banks. In major banks ${ }^{1}$ asset quality related to this definition (7.2\%) nearly equals an average level across the banking system as a whole (7.3\%).

However, Bank of Moscow influences most on this group indicators. Since 2011, Bank of Moscow is subject to bank resolution regime. This bank holds mainly loss assets (following transfer of part of business to the parent bank in May 2016). As of 1 September 2016, the ratio of reserves against potential losses to total assets for Bank of Moscow constitutes 47\%. Without Bank of Moscow, asset quality (5.8\%) of major state banks is close to leaders.

The worst asset quality indicators are posted by private banks. Plus, in the group of large banks ${ }^{2}$ the share of bad assets $(9.5 \%)$ is higher than in small and medium banks (8.7\%).

In certain segments of the credit market Sberbank is the leader regarding credit portfolio quality. At the same time, foreign banks preserve high asset quality solely on the corporate segment of the credit market. In the retail

1 Banks of VTB group (VTB, VTB24, and Bank of Moscow), RSHB, GPB.

2 Banks part of 30 largest on assets volume, along with state banks and banks owned by non-residents. 
segment owing to certain banks specializing on consumer lending total quality of consumer loans are lower than in the banking sector as a whole. The same picture is characteristic for large private banks, which are outsiders in retail credit portfolio quality owing to certain banks focused on the consumer loans market where the share of arrears exceed $40 \%$. In the corporate lending, on the contrary, the worst situation regarding the quality of loans is being observed in small and medium banks, which is explained probably by a lack of access for these banks to lending to the most reliable borrowers from among large businesses.

Table 1

INDICATORS OF ASSET QUALITY OF AS OF 1.09.2016, \%

\begin{tabular}{|l|c|c|c|}
\hline & $\begin{array}{c}\text { Ratio of total } \\
\text { reserves against } \\
\text { potential losses } \\
\text { to total assets }\end{array}$ & $\begin{array}{c}\text { Share of past } \\
\text { due debts on } \\
\text { retail loan }\end{array}$ & $\begin{array}{c}\text { Share of past } \\
\text { due debts on } \\
\text { corporate loans }\end{array}$ \\
\hline Banking system & 7.3 & 9.0 & 6.6 \\
\hline Sberbank & 5.3 & 4.7 & 3.4 \\
\hline Large state banks & 7.2 & 7.8 & 7.1 \\
\hline $\begin{array}{l}\text { Banks owned by } \\
\text { non-residents }\end{array}$ & 5.5 & 10.6 & 4.3 \\
\hline Large private banks & 9.5 & 17.2 & 7.0 \\
\hline Small and medi- & 8.7 & 13.7 & 11.8 \\
\hline um banks & & &
\end{tabular}

Slowdown of bad debts growth has affected the banking profit. In 2016, banks significantly reduced deductions to reserves against specified deposit liabilities, which resulted in growth of a positive performance outcome. For example, over 8 months of 2016, banking profit constituted Rb 532bn, which is seven times higher performance result for the same period of 2015. In 2016, return on assets has moved up to $1.0 \%$ in annual terms ( $0.2 \%$ a year earlier).

Such sharp increase of profit in comparison with the previous year is due more likely to the base effect - sharp decline of the last year than a final recovery of profitability in the banking activity. The record volume of profit was generated during the first eight months of 2012 when banks earned $\mathrm{Rb} 678 \mathrm{bn}$ and return on assets (ROA) came to $2.4 \%$ in annual terms.

The most notable contribution to an increase in the profit volume of the banking sector was due to a reduction of deductions to reserves against potential losses from loans and other assets. Moreover, profit has gone up from regular banking transactions minus operations with reserves and revaluation (Table 2).

Table 2

MAIN FACTORS OF BANKING SECTOR PROFIT IN 2015-2016, RB BN

\begin{tabular}{|l|c|c|c|}
\hline & \multicolumn{2}{|c|}{2015} & 2016 \\
\cline { 2 - 4 } & $\begin{array}{c}\text { January- } \\
\text { August }\end{array}$ & Total for year & $\begin{array}{c}2016 \\
\text { January- } \\
\text { August }\end{array}$ \\
\hline $\begin{array}{l}\text { Bank profit before taxes } \\
\begin{array}{l}\text { Growth of reserves against } \\
\text { potential losses }\end{array}\end{array}$ & 76 & 192 & 532 \\
\hline $\begin{array}{l}\text { Profit from revaluation of for- } \\
\text { eign currency accounts }\end{array}$ & 288 & 430 & 397 \\
\hline $\begin{array}{l}\text { Profit minus operations with } \\
\text { reserves and revaluation }\end{array}$ & 727 & 1114 & 17 \\
\hline
\end{tabular}


Despite such positive effect for the current performance result of the banking sector, the bad debt issue still remains unresolved. During the previous crisis (in 2008-2010), no systemic measures were implemented aimed at dealing with it. It resulted in the fact the nominal volume of generated reserves against potential losses has not been decreasing. Improvement of relative indicators of bank asset quality was owing to exclusively recovery of the banking sector growth and the new (current) crisis commenced from inferior positions than the previous one. Repetition of the same situation means that until the economy begins to display sustainable growth (without which no lending and bank asset growth can be possible), bad debt will continue to be a serious burden for banks and pose an obstacle to their development. 